\title{
Klimadebatten \\ - det geologiske perspektiv
}

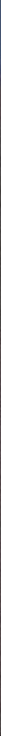

Siden midten af 1980'erne har de danske vintre varet proget af kraftige lavtryk med hyppige storme som denne ved Skallerup Klit, 22. februar 2008. Dette er bare ét af de mange tegn på igangveerende klimacendringer. (Foto Leo Odgaard)

Af Bent Odgaard, Geologisk Institut, Aarhus Universitet

Det geologiske tidsperspektiv og geologiske data har for alvor slået igennem i klimadebatten. Dette afsløres bl.a. gennem den stigende vægt, der lægges på palæoklima i rapporterne fra IPCC (Intergovernmental Panel on Climate Change). Den seneste og fjerde rapport fra 2007 rummer således et helt selvstændigt kapitel om palæoklima på ikke mindre end 60 sider. Størst opmærksomhed er der lige nu på geologiske analoger, på drivhusgasser i fortiden samt på tidsserier med høj opløsning.

Hvad er det generelle forhold mellem $\mathrm{CO}_{2}$ og temperatur på Jorden? Hvilke mekanismer er generelt de vigtigste udløsende faktorer for klimaændringer? Er den igangværende klimaændring usædvanlig? Bevirker vi mennesker, at hyppigheden af storme stiger? Spørgsmål af den type tegner dagsordenen for vores klimadebat, og de kan ikke belyses fyldestgørende uden at inddrage geologiske data. Det har geologer jo altid været overbeviste om, men det nye er, at andre i høj grad har fået øje på det. Det er således en fornøjelse at gennemlæse IPCCs seneste rapport med dens grundige gennemgang af fortidige klimaændringer og diskussion af disses mekanismer. Årsagerne til denne succes for geologien er flere. De drejer sig dels om tidsopløsning, dels om metodeudvikling og endelig om relevante analoger til vores nuværende situation.

\section{Fra år til år}

Høj tidsopløsning er vigtig, fordi data skal kunne afspejle de processer, som er relevante for os i dag, og som har politisk fokus. De meget succesrige boringer gennem den grønlandske indlandsis med deres tidsserier af klimaproxyer med ekstremt høj og præcis tidssopløsning (op til års- eller endog sæsonopløsning) har udgjort et vigtigt brohoved for det geologiske tidsperspektiv i klimadebatten. Tilsvarende tidsopløsning findes $i$ træringsserier og $i$ varvige sedimenter og disse tidsserier vil givet få endnu større opmærksomhed i fremtiden. Med sådanne serier kan vi bl.a. undersøge variabiliteten i klima og økosystemer under naturlige klimaer. Vi kan undersøge følsomheden over for klimaændringer i geologiske

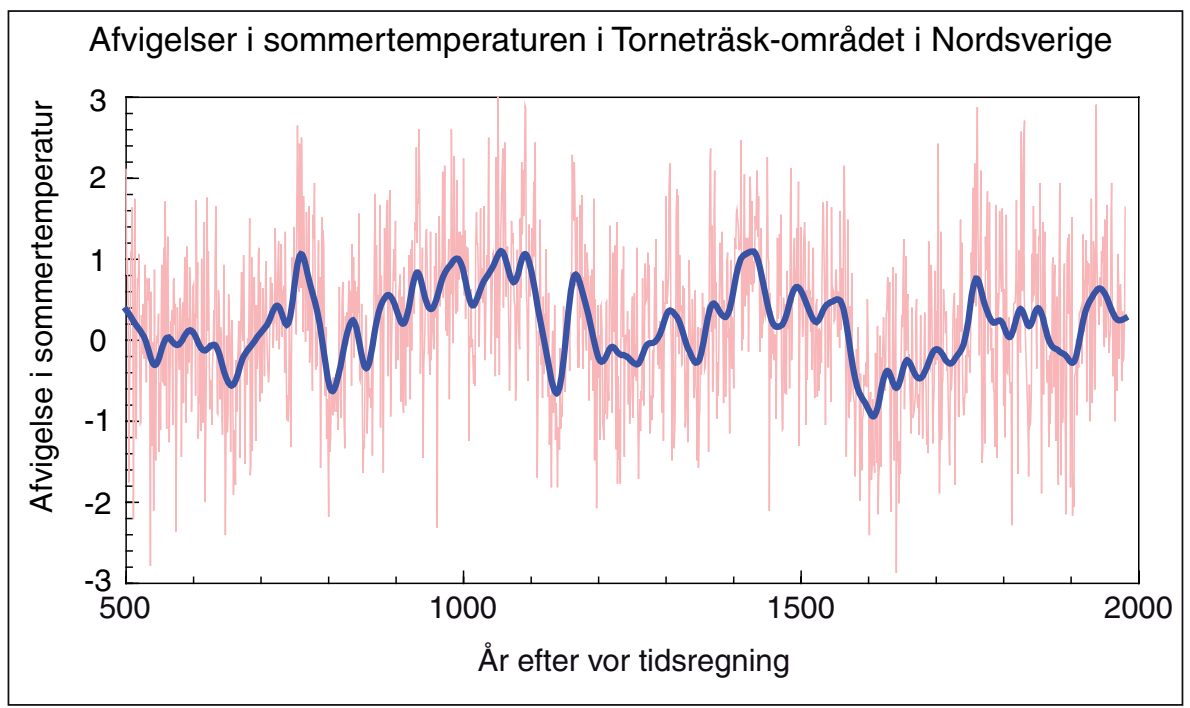

Afvigelser i sommertemperaturen i Torneträsk-området i Nordsverige gennem de sidste 1.500 år kan estimeres vha. bredden af årringe i fossile fyrrestammer. Den røde kurve viser enkeltårsvardier, den blå kurve et er løbende gennemsnit ( $n=50$ år). Bemcerk den lille istid fra slutningen af 1500-tallet til midten af 1700-tallet. (Grafik: Efter Briffa (2000) 
og økologiske systemer, og om der er nogen træghed, tidsforskydning eller modsat en forstærkende feedback-mekanisme i deres respons.

\section{Præcist hvor varmt?}

I debatten efterspørges præcise tal for fortidens klima. Bortset fra de sidste 150-200 år har vi jo ikke lige data aflæst på termometre og standardiserede nedbørsmålere og må $\mathrm{i}$ stedet bruge geologiske data, såkaldte proxier som afspejler klimaet i fortiden. Disse proxy-data skal tolkes, før de kan anvendes, og netop i denne tolkning er der sket store fremskridt i form af præcision. Eksempelvis anvendes bredden af træringe som proxy for fortidens klima. Om træringe primært afspejler temperatur eller nedbør eller noget helt tredje må for hver region undersøges ved at sammenligne træringene for de sidste 150 år med målte klimaserier. Træringe fra fyr i Nordskandinavien afspejler således primært sommertemperaturen, fordi det er den, der er begrænsende for væksten i dette område. Træringe fra Danmark er ikke så lette at tolke klimatisk, fordi klimaet her ikke i samme grad er begrænsende for træernes vækst. Er der først etableret en god statistisk sammenhæng mellem klima og træringe kan træringe målt på daterede, fossile stammer bruges direkte som mål for fortidens klima og med meget høj tidsopløsning.

Pollen, foraminiferer og øvrige mikrofossiler er eksempler på andre proxy-typer. Gennem de seneste to årtier er der sket en revolution i muligheden for at estimere fortidigt klima ud fra selskaber af sådanne mikrofossiler. Der foreligger således nu en række numeriske og statistiske teknikker til at sammenholde datasæt af moderne selskaber af fx pollen eller foraminiferer med moderne klima og derefter bruge denne sammenhæng til at estimere klimaet kvantitativt i fortiden ud fra fossile selskaber. Antagelserne bag disse redskaber er bl.a.,

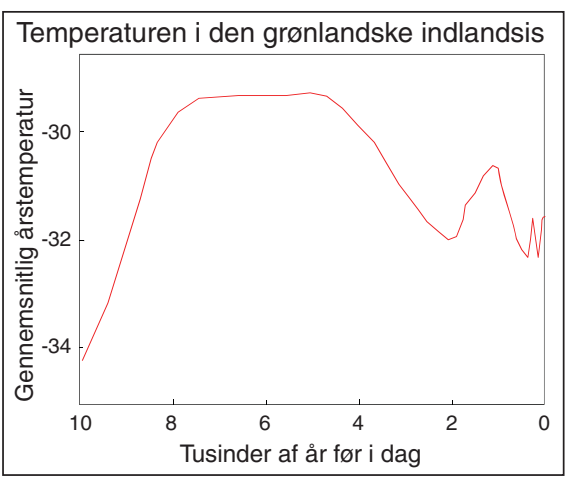

Temperaturen i den grønlandske indlandsis gemmer så at sige på oplysninger om temperaturen, dengang isen blev dannet. Kurven her viser den gennemsnitlige årstemperatur midt på iskappen gennem de sidste 10.000 år. Specielt i den celdre del er kurven udjcevnet på grund af isens varmeledende evne.(Grafik: Efter Dahl-Jensen mfl. (1998))

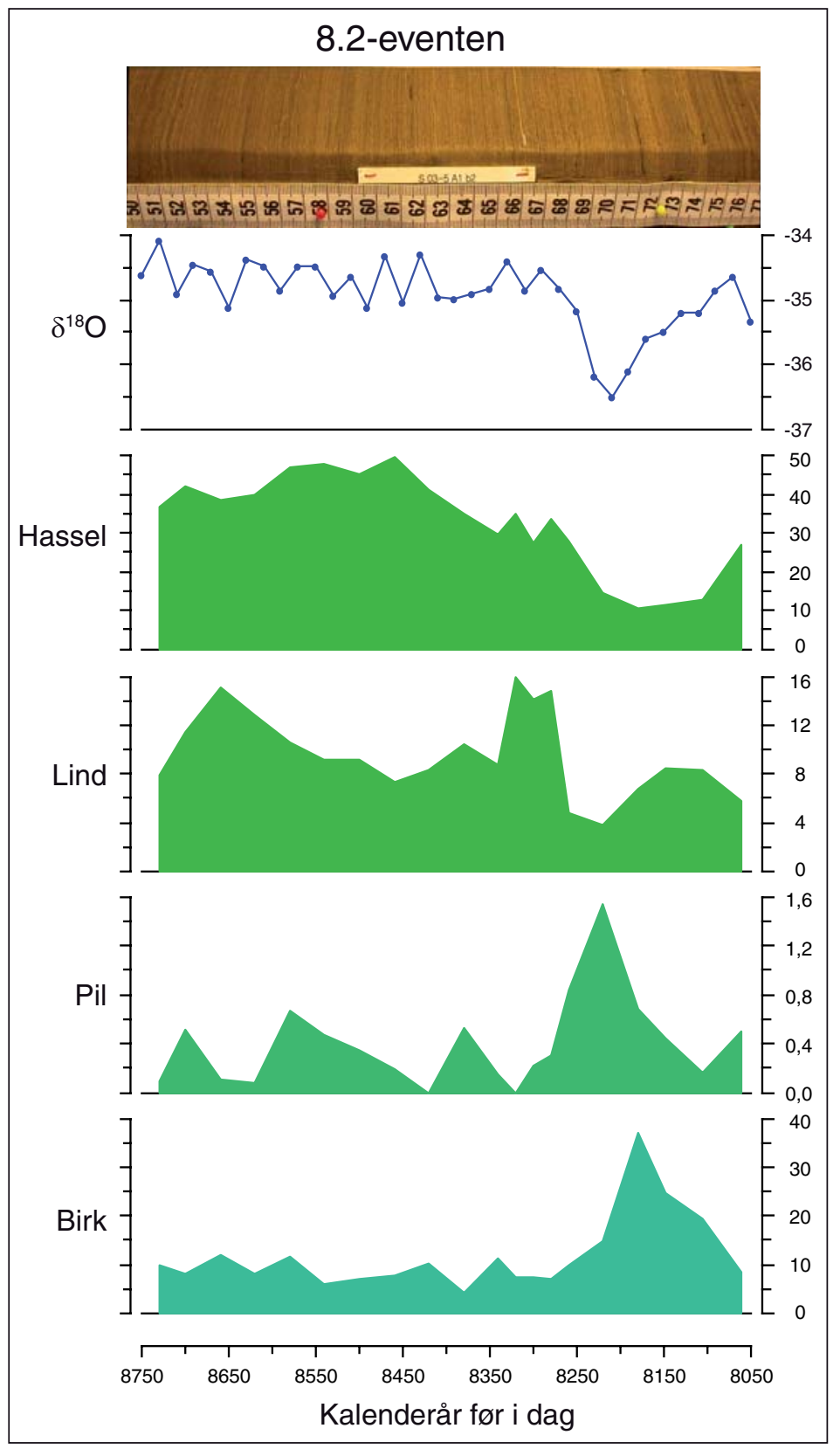

$\delta^{18} \mathrm{O}$-signalet $\mathrm{i}$ den grønlandske iskerne GISP2 (øverste kurve) afspejler et temperaturfald for ca. 8250 år siden, den såkaldte 8.2-event. I Sarup Sø på Fyn aflejredes der på den tid årsvarv med lyse, kalkrige lag om sommeren og mørkere lag, efterår, vinter og forår. Pollen i den varvige serie afspejler cendringerne $i$ søen og dens opland som respons på klimacendringen. Den første reaktion på 8.2-eventen er en tilbagegang i hassel og lind. I stedet breder der sig en vegetation af først pil, dernoest birk, som igen går tilbage, da klimaet finder tilbage til sit tidligere leje. Enheden på målebåndet langs sedimentkernen er cm. (Grafik:Forfatteren)

at klimaet $i$ dag er en begrænsende faktor for arternes udbredelse, og at udbredelsen er i ligevægt med klimaet. Det sidste viser sig desværre ikke altid at være tilfældet, og der er metodisk et behov for i højere grad at fokusere på de grupper, hvor en klimatisk ligevægt kan dokumenteres.

Et klassisk spørgsmål i klimadebatten er, om klimaet nogensinde har været varmere end i dag. På trods af nogle tilbageværende metodiske problemer kan geologien let besvare dette spørgsmål: Jo da, vi har sandelig haft varmere klima tidligere i Kvartærtiden, bare den sidste mellemistid, Eem-tiden (130.000-116.000 før nu), var et par grader varmere end i dag. Og selv i vores egen varmetid, Holocæn, var det på den nordlige halvkugle varmere for ca. 8.000-6.000 år siden end i dag. Så temperaturen i sig selv er vel ikke noget problem - eller hvad?

\section{$\mathrm{CO}_{2}$ som i nutiden?}

Der er i klimadebatten stor fokus på, om vores nuværende situation er unik, specielt om koncentrationen af drivhusgasserne $\mathrm{i}$ atmosfæren er højere end nogensinde før. 
Det argument, der har været mest udslagsgivende i diskussionen om menneskets påvirkning af klimaet, er, at modeller, der udelukkende baseres på naturlige processer (herunder variation $i$ solaktivitet og $i$ vulkanudbrud), ikke kan forklare den observerede stigning i temperaturen over de sidste ca. 30 år. Kun når ændringer i drivhusgasserne $\left(\mathrm{CO}_{2}, \mathrm{CH}_{4}\right.$ og $\left.\mathrm{N}_{2} \mathrm{O}\right)$ inddrages i modellerne, kan de bringes til at være i overensstemmelse med den observerede temperaturudvikling. Disse resultater har derfor medført en stor interesse for, hvor højt atmosfærens indhold af drivhusgasser var i fortiden, og om koncentrationen af disse gasser nogensinde før har ændret sig med den hastighed, der er observeret over de sidste 50 år. Lidt bredere formuleret drejer dette spørgsmål sig om, hvorvidt der har været en generel sammenhæng mellem mængden af drivhusgasser og klimaet.

EPICA-projektets boringer gennem den antarktiske is har nu tilvejebragt data med høj opløsning for klimaændringer gennem de sidste 800.000 år. Målinger af drivhusgasser i luftbobler i isen er publiceret for perioden 0 - 640.000 år, og de viser, at på intet tidspunkt i denne periode var niveauet for gasserne så højt som i dag. De viser også en generel positiv korrelation mellem drivhusgasser og temperatur, og denne sammenhæng afspejler formodentlig en positiv feedback-mekanisme med større frigivelse af gasser fra oceanerne under interglaciale forhold. Den ændring i atmosfærens indhold af drivhusgasser, som vi har set gennem de sidste 50 år, ligner den, der normalt sker på overgangen fra en istid til en mellemistid, men nu starter ændringen fra et mellemistidsniveau og med en hastighed, der er 2 til 3 størrelsesordner højere end afspejlet i iskernernes vidnesbyrd fra de forudgående 640.000 år!

Men har atmosfærens indhold af $\mathrm{CO}_{2}$ da aldrig været så høj som i dag? Jo, men vi skal formodentlig så langt tilbage som til Pliocæn for at finde eksempler på højere kuldioxidindhold. De geologiske data tyder altså på, at vi er på vej ind i en unik situation, hvor drivhusgasser ikke kun med-

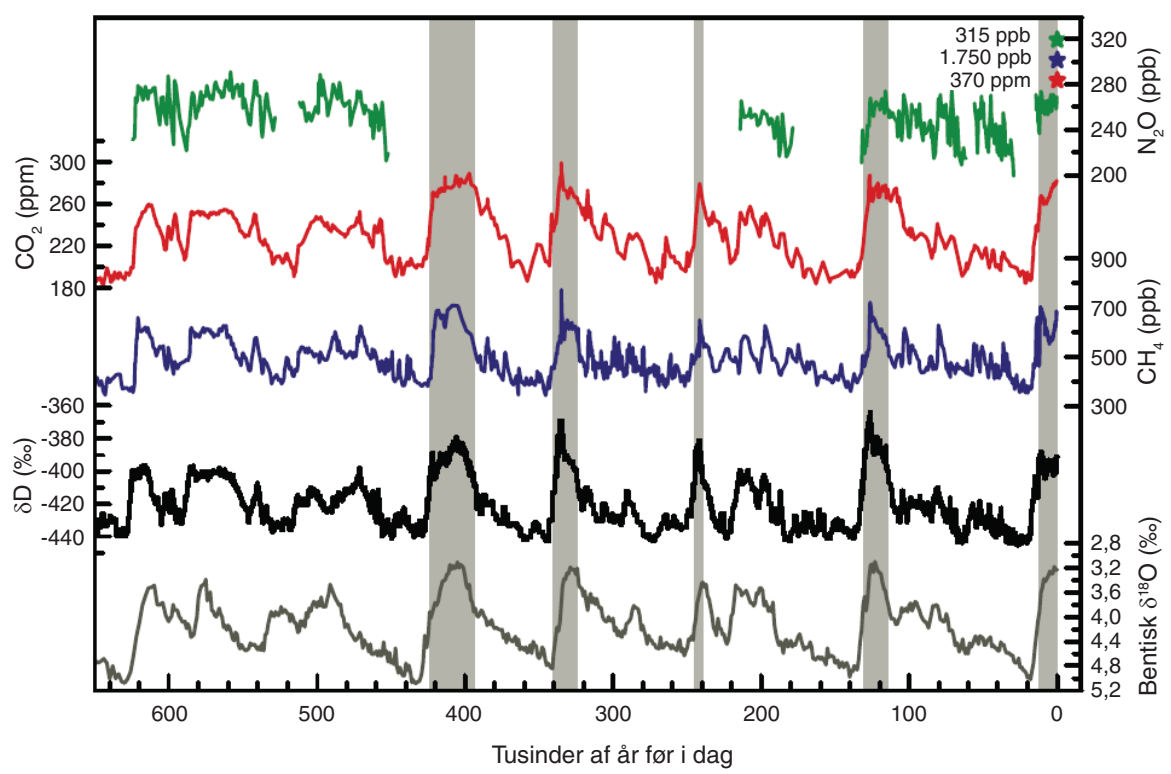

Tidsserier gennem de sidste 640.000 år af koncentration af drivhusgasser målt $i$ bobler $i$ antarktiske iskerner (grøn: $\mathrm{N}_{2} \mathrm{O}$, rød: $\mathrm{CO}_{2}$, bla: $\mathrm{CH}_{4}$ ) samt isotopen deuterium (sort). De tre farveder stjerner viser det moderne niveau af de tre gasser. Den nederste kurve viser $\delta^{18} O i$ bundlevende foraminiferer, en proxy for moengden af is på kloden (OBS! Skalaen er vendt). De lodrette grå bjcelker angiver mellemistider. Efter Jansen mfl. (2007).

virker til klimaændringer gennem positiv feedback, men også bliver en primær mekanisme til klimaændring.

\section{Klima og geologer}

Geologer udmærker sig i forhold til mange andre naturvidenskabelige kandidater ved deres gode forståelse for naturens foranderlighed. For en geolog er nutidens klima således bare ét eksempel blandt mange på, hvordan det kunne være. Det er vigtigt, at vi bringer denne forståelse ind i klimadebatten, men lige så væsentligt, at vi bruger relevant viden og relevante eksempler fra fortiden. Relevant betyder her på den rigtige skala - i tid og rum - samt under betingelser, som er sammenlignelige med de nuværende eller kommende. Hos en del geologer kan der mødes en vis afslappethed over for kommende klimaændringer, idet disse i forhold til ændringer i geologisk tid kan synes ubetydelige. Her er det imidlertid vigtigt, at huske den unikke situation, vi nu befinder os i, hvor jordens overfladeareal er næsten maksimalt udnyttet af mennesket, og hvor selv mindre ændringer i livsvilkår kan føre til voldsomme demografiske ændringer i form af flygtningestrømme og strid om territoriale krav. Heri ligger efter min mening den voldsomste udfordring når - ikke hvis - klimaet ændrer sig.

\section{Referencer:}

Briffa, K.R. 2000. Annual climate variability in the Holocene: interpreting the message of ancient trees. - Quaternary Science Reviews: 19: 87-205.

Dahl-Jensen, D. mfl. 1998. Past temperatures directly from the Greenland ice sheet. - Science 282:268-271.

Jansen, E. mfl. (2007). Palaeoclimate. - I: Climate Change 2007: The Physical Science Basis (Solomon et al.). Cambridge University Press. 